Brain Research Reviews, 56: 183-197

\title{
Hyperammonemia-induced toxicity for \\ the developing central nervous system
}

\section{Laurène Cagnon and Olivier Braissant.}

\author{
Clinical Chemistry Laboratory, \\ Centre Hospitalier Universitaire Vaudois and University of Lausanne, \\ CH-1011 Lausanne, Switzerland.
}

Total number of pages (including figures and tables): $\mathbf{5 3}$

Number of figures: 3

Number of tables: 1

\section{Correspondence to: Olivier Braissant,}

Clinical Chemistry Laboratory,

Centre Hospitalier Universitaire Vaudois and University of Lausanne

CI 02/33, Avenue Pierre-Decker 2

CH-1011 Lausanne, Switzerland

Tél : (+41.21) 314.41.52

Fax : (+41.21) 314.35.46

e-mail: Olivier.Braissant@chuv.ch 


\section{Abstract}

In pediatric patients, hyperammonemia can be caused by various acquired or inherited disorders such as urea cycle deficiencies or organic acidemias. The brain is much more susceptible to the deleterious effects of ammonium during development than in adulthood. Hyperammonemia can provoke irreversible damages to the developing central nervous system that lead to cortical atrophy, ventricular enlargement and demyelination, responsible for cognitive impairment, seizures and cerebral palsy. Until recently, the mechanisms leading to these irreversible cerebral damages were poorly understood. Using experimental models allowing the analysis of the neurotoxic effects of ammonium on the developing brain, these last years have seen the emergence of new clues showing that ammonium exposure alters several amino acid pathways and neurotransmitter systems, as well as cerebral energy metabolism, nitric oxide synthesis, oxidative stress, mitochondrial permeability transition and signal transduction pathways. Those alterations may explain neuronal loss and impairment of axonal and dendritic growth observed in the different models of congenital hyperammonemia. Some neuroprotective strategies such as the potential use of NMDA receptor antagonists, nitric oxide inhibitors, creatine and acetyl-L-carnitine have been suggested to counteract these toxic effects. Unraveling the molecular mechanisms involved in the chain of events leading to neuronal dysfunction under hyperammonemia may be useful to develop new potential strategies for neuroprotection. 


\section{Section}

Disease-related neuroscience

\section{Keywords}

Hyperammonemia, ammonium, brain, development, neurotoxicity, neuroprotection

\section{Abbreviations}

ASL: argininosuccinate lyase; APV: 2-amino-5-phosphonovaleric acid; ASS: argininosuccinate synthetase; CATs: cationic amino acid transporters; ChAT: choline acetyltransferase; CNS: central nervous system; CPS-1: carbamoylphosphate synthetase 1; CSF: cerebrospinal fluid; GS: glutamine synthetase; HHH: hyperammonemiahyperornithinaemia-homocitrullinuria syndrome; IQ: intellectual quotient; KO: knock-out; LTP: long term potentiation; MAP-2: microtubule associated protein 2; MAPK: mitogenactivated protein kinase; MPT: mitochondrial permeability transition; MRI: magnetic resonance imaging; NFM: medium weight neurofilament protein; $\mathrm{NH}_{4}^{+}$: ammonium; NMDA: N-methyl-D-aspartate; NO: nitric oxide; NOS: nitric oxide synthase; ORNT1: ornithine citrulline antiporter 1; OTC: ornithine transcarbamoylase; $\mathrm{y}^{+} \mathrm{LAT} 1$ : cationic amino acid $\mathrm{y}^{+} \mathrm{L}$-associated transporter 1 (system $\mathrm{y}^{+} \mathrm{L}$ ). 


\section{Contents}

\section{1: Introduction}

\section{2: Hyperammonemia in newborns and infants}

2.1: Clinical presentation and treatments

2.2: Irreversible effects on the developing brain

3: Experimental models for the study of the effects of hyperammonemia on the developing CNS

3.1: The sparse-fur mouse

3.2: Knock-out mice

3.3: Rats models of congenital hyperammonemia

3.4: Reaggregating brain cell 3D cultures

3.5: Other models of hyperammonemia

\section{4: Toxicity of ammonium on experimental models of the developing CNS}

4.1: Amino acids disturbances

4.1.1: Glutamine

4.1.2: Glutamate

4.1.3: Arginine

4.1.4: Other amino acids

4.2: Alteration in the neurotransmitter systems

4.2.1: Glutamatergic system

4.2.2: Cholinergic system

4.2.3: Serotoninergic system

4.3: Cerebral energy deficit

4.4: Alteration of nitric oxide synthesis

4.5: Oxidative stress

4.6: Induction of mitochondrial permeability transition

4.7: Impairment of axonal and dendritic growth

4.8: Disturbances in signaling transduction pathways

4.9: Impairment of cognitive performance

5: Conclusion and perspectives for neuroprotection against ammonium toxicity on the developing CNS

Acknowledgments

References 


\section{1: Introduction}

Ammonia is produced by amino acid metabolism and intestinal urease-positive bacteria, and is mostly present as ammonium $\left(\mathrm{NH}_{4}{ }^{+}\right)$at physiological $\mathrm{pH}$ in the circulation. $\mathrm{NH}_{4}^{+}$is maintained at low concentrations (50-150 $\mu \mathrm{M}$ in preterm neonates, 50-75 $\mu \mathrm{M}$ in term neonates, and $<50 \mu \mathrm{M}$ in adults; Donn and Banagale, 1984) by the urea cycle (Fig. 1), which converts $\mathrm{NH}_{4}{ }^{+}$to urea in the liver prior to excretion of urea by the kidneys (Morris, 2002). The complete urea cycle is expressed only in the liver. In particular, the brain is unable to convert $\mathrm{NH}_{4}^{+}$to urea due to its lack of carbamoylphosphate synthetase 1 (CPS-1) and ornithine transcarbamoylase (OTC), despite expressing argininosuccinate synthetase (ASS), argininosuccinate lyase (ASL) and arginase 1. In the central nervous system (CNS), $\mathrm{NH}_{4}{ }^{+}$is maintained however at relatively low concentrations by the action in astrocytes of glutamine synthetase (GS), which converts glutamate and $\mathrm{NH}_{4}{ }^{+}$to glutamine (Felipo and Butterworth, 2002).

In adults, liver failure results in hyperammonemia responsible of a potentially severe neuropsychiatric disorder named hepatic encephalopathy, that progressively leads to altered mental status and coma. The symptoms of hepatic encephalopathy in adults can be reversed when $\mathrm{NH}_{4}{ }^{+}$concentration returns to normal levels, provided that terminal cerebral edema is not reached. In pediatric patients, hyperammonemia can be caused by various inherited or acquired disorders (Table 1) (Donn and Banagale, 1984; Leonard and Morris, 2002), the most frequent being urea cycle disorders with an overall prevalence estimated at 1:8200 in the United States (Gropman and Batshaw, 2004). The developing brain is much more susceptible to the deleterious effects of $\mathrm{NH}_{4}^{+}$than is the brain of the adult. Hyperammonemia can provoke irreversible damages to the developing CNS, with presentation symptoms such as cognitive impairment, seizures and cerebral palsy (Flint Beal and Martin, 1998). 
Hyperammonemic neonates and infants develop cortical atrophy, ventricular enlargement, demyelination or gray and white matter hypodensities (Msall et al., 1984; Harding et al., 1984; Filloux et al., 1986; Dolman et al., 1988; Wakamoto et al., 1999; Takeoka et al., 2001; Yamanouchi et al., 2002; Takanashi et al., 2003b; Majoie et al., 2004). The extent of the irreversible damages depends on the maturation of the brain and on the magnitude and duration of the exposure to $\mathrm{NH}_{4}^{+}$. Irreversibility mainly occurs in case of prolonged hyperammonemic crises and/or when blood $\mathrm{NH}_{4}{ }^{+}$reaches levels between 200 and $500 \mu \mathrm{M}$, during the two first years of life (Msall et al., 1984; Uchino et al., 1998; Bachmann, 2002; Bachmann, 2003). This review will focus on the most recent advances in understanding the toxicity of hyperammonemia on the developing CNS.

\section{2: Hyperammonemia in newborns and infants}

\section{1: Clinical presentation and treatments}

Most patients with urea cycle disorders commonly present in the neonatal period with nonspecific symptoms, which can be poor feeding, vomiting, somnolence, irritability and tachypnoea (Leonard and Morris, 2002). With the rise in plasma $\mathrm{NH}_{4}^{+}$, symptoms can progress rapidly towards hypothermia, lethargy and coma (Summar, 2001). In particular, hyperammonemia generates edema in CNS, due to astrocyte swelling, which leads to an increase in intracranial pressure and to brain herniation (Cordoba and Blei, 1996; Norenberg et al., 2005). Neurological problems such as seizures, abnormal posture and neuromuscular irritability are frequent and accentuated depending on the degree of the CNS swelling and of the rise of pressure on brain stem (Butterworth, 1998). Brain edema leads to hyperventilation and respiratory alkalosis, progressing to hypoventilation and apnoea (Brusilow and Maestri, 
1996). Untreated, most babies will die, often with complications such as cerebral or pulmonary haemorrhage. Survivors from these episodes will eventually exhibit mental retardation, the degree of retardation correlating with the level and duration of neonatal hyperammonemia (Msall et al., 1984; Leonard and Morris, 2002), with no normal cognitive outcome, or a fatal issue, occuring if plasma $\mathrm{NH}_{4}{ }^{+}$exceeds $300 \mu \mathrm{M}$ at the presentation of the patients or reaches a peak above $500 \mu \mathrm{M}$ (Bachmann, 2003; Enns et al., 2007).

In patients presenting with partial enzyme deficiencies of the urea cycle, the first recognized clinical episode may be delayed for months or years. $\mathrm{NH}_{4}{ }^{+}$accumulation may be triggered by illness or catabolic stress resulting in multiple mild elevations of plasma $\mathrm{NH}_{4}{ }^{+}$concentrations. The hyperammonemia is then less severe than in newborn patients and the symptoms milder (Takanashi et al., 2002). In most patients late-onset hyperammonemic episodes are marked by loss of appetite, cyclic vomiting, lethargy, and behavioral abnormalities (Smith et al., 2005; Harada et al., 2006). Protein avoidance may also be one of the symptoms found in patients with partial enzyme deficiencies, especially in female OTC deficient patients (Scaglia et al., 2002). Many of those patients also remain mentally retarded or have learning difficulties.

The immediate therapeutic goal for neonatal hyperammonemic conditions is the quick removal of ammonia. Proteins should be restrained from diet, in particular in case of severe neonatal hypermamonemia. When the metabolic alteration cannot be controlled rapidly, patients have to be dialyzed, preferentially through hemodialysis, hemodiafiltration or continuous veno-venous hemofiltration (Leonard et al., 2007). To reverse catabolism in this critical phase, patients are given glucose intravenously, together with spare insulin infusion to avoid swings in glucose levels (Summar, 2001). The metabolic control of $\mathrm{NH}_{4}{ }^{+}$levels in this neonatal acute phase makes use of intravenous infusion of sodium benzoate and sodium 
phenylacetate, that create alternative pathways for nitrogen excretion (Brusilow et al., 1979; Shih, 2007). Following these short term measures, the long term control of $\mathrm{NH}_{4}{ }^{+}$uses oral treatments with the same compounds or sodium phenylbutyrate, in combination with a lowprotein diet (Feillet and Leonard, 1998; Berry and Steiner, 2001; Batshaw et al., 2001; Enns et al., 2007). Acute intercurrent crisis of hyperammonemia are treated again with intravenous infusion of these compounds. Moreover, nitrogen excretion is promoted by large doses of arginine given to ASS and ASL deficient patients, while citrulline is preferred for the treatment of CPS-1 and OTC deficiencies (Brusilow et al., 1979; Leonard and Morris, 2002). Orthotopic liver transplantation has to be considered for the more severe urea cycle defects such as CPS-1 and OTC deficiencies (Lee and Goss, 2001). Even with early diagnosis and intensive treatment, mortality is high and neurological problems are frequent in survivors (Bachmann, 2003).

Very recently, new additional measures have been proposed, in combination with the conventional treatments described above, for the prospective treatment of babies at risk of neonatal hyperammonemia because of familial history (Leonard et al., 2007).

\section{2: Irreversible effects on the developing brain}

Mental retardation, as symptom of irreversible damage to the developing brain, is observed in the majority of children surviving with inborn errors of urea cycle. Important decrease in intellectual quotient (IQ), often combined with one or more neurological disabilities, is found in these patients, with strong correlations between the degree of IQ decrease, the level of developmental disabilities, the gravity of brain abnormalities as observed by computed tomography or magnetic resonance imaging (MRI), and the level, the duration and the age at 
onset of hyperammonemia (Msall et al., 1984; Nagata et al., 1991; Bachmann, 2003). Neonatal onset of hyperammonemia leads to the most severe brain damages and the least IQ score.

Brain MRI of patients with neonatal onset of hyperammonemia resulting from different urea cycle disorders have shown important volume loss of specific parts of the developing CNS (Msall et al., 1988). In particular, diffuse cortical atrophy and lesions in basal ganglia have been observed in OTC and CPS-1 deficient patients, sometimes with cortical multicystic formations and appearance of myelination delay (Yamanouchi et al., 2002; Takanashi et al., 2003b). The same observations were also made in an ASS deficient neonate, with also lesions in thalamic nuclei, and a probable injury of the oligodendro-axonal unit (Majoie et al., 2004). MRI observation of brain lesions within the very few first days of life (0 to 8 days) in some patients with OTC, CPS-1 and ASS deficiencies suggests that some of these lesions or defects of development due to urea cycle diseases might be acquired already in utero (Harding et al., 1984; Filloux et al., 1986; Takeoka et al., 2001; Majoie et al., 2004). In particular, it was proposed that the hypomyelination found in OTC neonates might be due to prenatal damages to oligodendrocytes, and that the multiple bilateral cerebellar heterotopia observed in the same patients might be the consequence of an arrest of neuronal migration in the embryonic cerebellum (Harding et al., 1984). Since OTC deficiency is an X-linked disorder, it is conceivable that fetal metabolic insufficiencies may not be fully compensated by the maternal organism. Filloux et al. postulated that the brain lesions described in the first days of life represent the initial neuropathological manifestations that, in case of prolonged survival, lead in part to the atrophic and degenerative changes observed later (Filloux et al., 1986). 
Patients with later onset of hyperammonemia may have a normal neurodevelopment, if the diagnosis is made before they sustain an irreversible cerebral insult (Kurihara et al., 2003); however, many remain mentally retarded or have learning difficulties. Brain MRI of patients with late-onset OTC deficiency have shown injury to the cortex including acute ischemia, ventricular dilatation and defects of myelination (de Grauw et al., 1990; Kurihara et al., 2003; Takanashi et al., 2003a). Similar lesions were found in late onset CPS-1, ASS and arginase 1 deficiencies (Call et al., 1984; Scaglia and Lee, 2006; Choi et al., 2006; Kim et al., 2006), as well as in patients with organic acidemias such as propionic acidemia, or with hyperammonemia-hyperornithinaemia-homocitrullinuria $(\mathrm{HHH})$ syndrome, and presenting with a normal neonatal life (Harding et al., 1991; Salvi et al., 2001).

The rare analyzed autopsy cases of urea cycle deficiencies reveal, depending on the age of death and whether they developed neonatal or late onset hyperammonemia, microcephaly, shrinkage of hemispheres with appearance of multiple cysts, ventricular dilatation, atrophy or necrosis of various nuclei (particularly in caudate putamen, thalamus and hypothalamus) and defects of myelination (Dolman et al., 1988; Takeoka et al., 2001; Yamanouchi et al., 2002). Microscopically, the brain tissue often appears spongy with extensive neuronal loss (particularly in cortex and hippocampus), is markedly gliosed and presents astrocytes with water-clear, oval nuclei characteristic of Alzheimer's type II astrocytes. Recently, emperipolesis, i.e. the active penetration of one cell by another one which remains intact, has also been described in the cerebral white matter of a 46-years old patient with ASS deficiency, where oligodendrocytes have been shown engulfed within hypertrophic astrocytes (Nishie et al., 2006). 
In contrast with the developing brain, hyperammonemia (generally associated with liver failure) does not result in significant neuronal loss or structural damage to neurons in the adult brain (Butterworth, 2003).

\section{3: Experimental models for the study of the effects of hyperammonemia on the developing CNS}

\section{1: The sparse-fur mouse}

The sparse-fur ( $s p f)$ mouse is an ideal animal model to study the effects of hereditary hyperammonemia, as this mouse has a single point substitution in the OTC gene, with an X linked transmission (Qureshi 1979, Veres 1987). Two mouse strains with OTC mutations have been described: sparse-fur (spf) and sparse-fur with abnormal skin and hair (spf ${ }^{a s h}$ ) (Doolittle et al., 1974; DeMars et al., 1976). The hepatic OTC activity is 5 to $10 \%$ in the spf ash and $13 \%$ in the spf, as compared to the normal mice (Qureshi and Rao, 1997). Adult spf/Y mice (12 weeks old) show plasma and brain $\mathrm{NH}_{4}{ }^{+}$levels increased 1.5 and 5 fold respectively (Ratnakumari et al., 1992). In these mice, a 3-fold increase in blood $\mathrm{NH}_{4}{ }^{+}$is observed immediately after weaning as compared to control litter mates, which is probably due to dietary change from mother's milk to the conventional laboratory chow and to the subsequent changes in the intestinal flora from non-urease producing to urease producing bacteria that increase blood $\mathrm{NH}_{4}{ }^{+}$level (Gushiken et al., 1985; Inoue et al., 1987). Recent analysis of the $s p f^{a s h}$ mice have shown that despite their reduced OTC activity, these mice are able to detoxify ammonia and keep normal ureagenesis when they are infused with a balanced, complete mixture of amino acids, while an unbalanced amino acid infusion (i.e. a glycinealanine mixture) make them hyperammonemic and decreases their ureagenesis (Marini et al., 2006b). This ability of spf mice to detoxify ammonia and keep normal ureagenesis under 
balanced amino acids is probably due to the presence of arginine in the complete mixture of amino acids. Neuropathologic studies in the spf mouse revealed similar brain alterations as those observed in patients with OTC deficiency. Spf mice exhibit an overall brain size reduction with a reduced volume of the striatum and ventricular enlargement (Hopkins et al., 1998).

\section{2: Knock-out mice}

Knock-out (KO) mice as models of other urea cycle deficiencies have been developed recently: ASL, arginase 1 and arginase 2 deficient mice, as well as double KO mice for arginases 1 and 2 (Iyer et al., 2002; Reid Sutton et al., 2003; Deignan et al., 2006). Homozygous $\mathrm{ASL}^{-/-}$null mice die within $48 \mathrm{~h}$ after birth with plasma $\mathrm{NH}_{4}{ }^{+}$increased 4 fold. Arginase $1 \mathrm{KO}$ mice and arginases 1/2 double $\mathrm{KO}$ mice die from hyperammonemia at 14 days postnatally, with a 10 -fold increase in plasma $\mathrm{NH}_{4}{ }^{+}$level, while arginase $2 \mathrm{KO}$ mice have no obvious phenotype (Iyer et al., 2002; Reid Sutton et al., 2003; Deignan et al., 2006). Neuropathological studies have not yet been published for these KO mice. Anyhow, as these enzymes are normally expressed in brain cells, ASL, arginase 1 and arginase 2 deficiencies may alter normal brain development independently of hyperammonemia (Braissant et al., 1999a; Yu et al., 2001), hampering thus the study of the specific effects of $\mathrm{NH}_{4}^{+}$toxicity on the developing CNS in these models.

\section{3: Rats models of congenital hyperammonemia}

In vivo, long-term effects of chronic hyperammonemia have also been studied in rat models of congenital hyperammonemia. Authors exposed rats to $\mathrm{NH}_{4}{ }^{+}$during prenatal and lactation periods by feeding the pregnant rats with an $\mathrm{NH}_{4}{ }^{+}$acetate-containing diet from day 1 of pregnancy until weaning (at postnatal day 21). After weaning, pups were also fed the $\mathrm{NH}_{4}{ }^{+}$ 
containing diet (Aguilar et al., 2000; Munoz et al., 2000). The amount of $\mathrm{NH}_{4}{ }^{+}$in the brain of these hyperammonemic rats increased 1.4 times compared to control rats (Munoz et al., 2000).

\section{4: Reaggregating brain cell 3D cultures treated with $\mathrm{NH}_{4} \mathrm{Cl}$}

Our research team has developed reaggregating brain cell 3D cultures as a valid experimental model to study the specific effects of $\mathrm{NH}_{4}{ }^{+}$toxicity on the developing CNS (Braissant et al., 1999b; Honegger and Monnet-Tschudi, 2001; Braissant et al., 2002; Braissant et al., 2006). These are primary cell cultures prepared from the CNS of rat embryos, containing all types of brain cells (neurons, astrocytes, oligodendrocytes and microglia) and consisting of even-sized, spherical structures that are maintained in suspension by constant gyratory agitation in a serum-free, chemically defined medium. Cells are able to migrate within the formed reaggregated structures, and to interact with each other by direct cell-cell contacts, as well as through exchange of nutritional and signaling factors. This tissue-specific environment enables aggregating neural cells to differentiate, and to develop specialized structures (synapses, myelinated axons) resembling those of the brain tissue (Honegger and MonnetTschudi, 2001). Aggregating cell cultures are therefore classified as organotypic cultures (Doyle et al., 1994). Chronic hyperammonemia is mimicked in this model by treating the cultures with $5 \mathrm{mM} \mathrm{NH}_{4} \mathrm{Cl}$ for 8 days (Braissant et al., 1999b; Braissant et al., 2002). We have thus shown that axonal growth, as well as medium weight neurofilament (NFM) expression and phosphorylation, are altered by $\mathrm{NH}_{4} \mathrm{Cl}$ exposure (Braissant et al., 2002). This occurs only in developing brain cell aggregates (treated from days 5 to 13: a period at which neurons progressively develop their processes) but not in more mature cultures (treated from day 20 to 28: a period at which neurons progressively undergo synaptogenesis and myelination) (Honegger and Monnet-Tschudi, 2001; Braissant et al., 2002). This difference in 
vulnerability of the brain depending on its maturation level is in line with clinical data showing that hyperammonemia causes irreversible CNS damages such as neuronal cell loss in neonates and infants but not in adults (Brusilow and Horwich, 2001). Compared to classical brain cell cultures, brain cell reaggregated cultures present the advantage to allow the study of irreversible $\mathrm{NH}_{4}^{+}$toxicity in a model that mimic brain complexity at different stages of maturation. In the same time, these cultures allow to study the effects of hyperammonemia devoid of confusing variables attributable to secondary effects of hyperammonemia found in animal models (Bachmann, 1992).

\section{5: Other models of hyperammonemia}

Hyperammonemia has been experimentally induced in vivo on adult rats by several other methods, including the intraperitoneal injection with $\mathrm{NH}_{4}{ }^{+}$-acetate or infusion with urease (Robinson et al., 1992b), $\mathrm{NH}_{4}{ }^{+}$-acetate containing diet (20\% weight) (Azorin et al., 1989) or portacaval anastomosis (Song et al., 2002). In vitro, toxic effects of $\mathrm{NH}_{4}^{+}$have been studied on primary cultures of neurons or astrocytes (Chan et al., 2000; Schliess et al., 2002; Jayakumar et al., 2006) and on hippocampal rat brain slices (Chepkova et al., 2006). These models have provided several clues for the mechanisms of $\mathrm{NH}_{4}{ }^{+}$toxicity on brain cells, but they do not allow the analysis of the effects of hyperammonemia on the developing CNS, in particular in its cellular complexity and the relationships between developing neurons and glial cells.

\section{4: Toxicity of ammonium on experimental models of the developing CNS}

\section{1: Amino acids disturbances}




\subsection{1: Glutamine}

As glutamine synthesis is the major brain pathway for the removal of $\mathrm{NH}_{4}^{+}$, hyperammonemic conditions with high levels of $\mathrm{NH}_{4}{ }^{+}$in CNS should increase the synthesis of brain glutamine. As a result, a 2 to 3 fold increase in brain glutamine was reported by proton spectroscopy in two females with OTC deficiency (Connelly et al., 1993). A 2-fold increase in glutamine level was also reported in the brain of spf mice (Inoue et al., 1987). These results are confirmed by in vitro studies showing that $\mathrm{NH}_{4} \mathrm{Cl}$ exposure of aggregating brain cell cultures increases their intracellular concentration of glutamine (Bachmann et al., 2004).

\subsection{2: Glutamate}

Glutamate concentrations are significantly reduced in cerebral cortex (but not in other brain regions) of spf mice as well as in $\mathrm{NH}_{4} \mathrm{Cl}$-exposed brain cell $3 \mathrm{D}$ cultures prepared from embryonic rat telencephalons (Ratnakumari et al., 1994a; Bachmann et al., 2004). This could be the result of increased glutamine formation from $\mathrm{NH}_{4}{ }^{+}$and glutamate or of a loss of glutamatergic neurons (Qureshi and Rao, 1997).

\subsection{3: Arginine}

Arginine is an essential amino acid for the foetus and the neonate, who however synthesize parts of their arginine needs through the combined expression of CPS-1, OTC, ASS and ASL in the intestine (Husson et al., 2003; Curis et al., 2005). In the adult, arginine is considered a conditionally essential amino acid, and its endogenous synthesis pathway is decoupled between CPS-1 and OTC expressed in the intestine (while ASS and ASL are repressed) and synthesizing citrulline, and ASS and ASL being induced in proximal tubule cells of the kidney, which synthesizes arginine from the incoming citrulline produced by intestine $(\mathrm{Wu}$ and Morris, 1998; Husson et al., 2003). As a consequence, patients with urea cycle disorders 
(except those with arginase 1 deficiency) have decreased plasma arginine concentrations and need a supplement of arginine to replace that which is not synthesized (Leonard and Morris, 2002; Scaglia et al., 2004; Scaglia and Lee, 2006). Severely affected CPS-1 and OTC deficient patients are better treated with citrulline rather than arginine (Leonard and Morris, 2002). As arginine is precursor for nitric oxide (NO) and creatine synthesis, urea cycle deficiencies can lead to disturbances of the citrulline-NO cycle (Fig. 2) (see 4.4: alteration of NO synthesis) and an alteration of creatine metabolism (Fig. 3) (see 4.3: cerebral energy deficit), including in brain cells (Braissant, 2007). Spf mice, which are deficient in their own arginine synthesis as are OTC-deficient patients, present decreased levels of arginine in their brain (Ratnakumari et al., 1996b). In contrast, experimental models with no evidence of arginine depletion show increased levels of arginine in brain cells placed under $\mathrm{NH}_{4}^{+}$ exposure, as it was shown in aggregating brain cell 3D cultures exposed to $\mathrm{NH}_{4} \mathrm{Cl}$ (Bachmann et al., 2004) and in rat cerebellar synaptosomes exposed to $\mathrm{NH}_{4}{ }^{+}$-acetate (Rao, 2002). This might be due to the $\mathrm{NH}_{4}{ }^{+}$-induced expression of ASS and ASL in astrocytes (Braissant et al., 1999b).

\subsection{4: Other amino acids}

Plasma ornithine and citrulline levels are low in spf mice (Qureshi and Rao, 1997). Interestingly, ornithine supplementation to hyperammonemic spf ${ }^{a s h}$ mice can decrease their hyperammonemia and restore their ureagenesis, suggesting that ornithine has the potential to correct OTC deficiency in spf ${ }^{\text {ash }}$ mice (Marini et al., 2006a). Finally, large neutral amino acids (tyrosine, phenylalanine, methionine, tryptophan and histidine) accumulates in the brain of spf mice (Bachmann and Colombo, 1984; Inoue et al., 1987).

\section{2: Alterations in the neurotransmitter systems}




\subsection{1: Glutamatergic system}

An hypothesis to explain the neuronal loss observed under hyperammonemia involves excitotoxicity injury through N-methyl-D-aspartate (NMDA) receptors. Although $\mathrm{NH}_{4}^{+}$is presumed to be the principal neurotoxin, there is evidence that other neurochemical alterations may also be involved. Tryptophan, which is increased under hyperammonemia (Bachmann and Colombo, 1984), can be oxidized to quinolinic acid, an excitotoxin acting on NMDA receptors. As a result of tryptophan increase, quinolinic acid is increased in the cerebrospinal fluid (CSF) of children with congenital hyperammonemia as well as in various regions of spf mice brain (Batshaw et al., 1993; Robinson et al., 1995). Infusion of quinolinic acid into the brain is associated with selective death of spiny neurons in the striatum (Schwarcz and Kohler, 1983; Robinson et al., 1995). This result is consistent with the loss of spiny neurons observed in the striatum in spf/Y mice (Robinson et al., 1995; Ratnakumari et al., 1995b) and suggests that $\mathrm{NH}_{4}^{+}$neurotoxicity may be mediated by quinolinic acid in patients with congenital hyperammonemia (Fig. 2).

The release of endogenous glutamate, induced by depolarization, from synaptosomes isolated from spf mice at 35 days is significantly elevated, while the uptake of glutamate into synaptosomes is significantly reduced (Rao and Qureshi, 1999). These results suggest that the level of extracellular glutamate is increased in the brain of spf mice. This is in accordance with the increased level of extracellular glutamate observed by microdialysis in rabbit with acute hyperammonemia as well as with experiments showing that $\mathrm{NH}_{4}{ }^{+}$leads to glutamate release from cultured astrocytes (de Knegt et al., 1994; Rose et al., 2005). Moreover, the astrocytic glutamate transporter GLAST is decreased under $\mathrm{NH}_{4}{ }^{+}$exposure, leading to a decreased re-uptake of extracellular glutamate (Fig. 2) (Chan et al., 2000). As a consequence of a persistent release of excess glutamate, a significant reduction in NMDA receptors has been shown in the cerebral cortex of spf mice (Hopkins and Oster-Granite, 1998; Rao and 
Qureshi, 1999). This down-regulation might be a mechanism of protection against excess stimulation of the NMDA receptors by glutamate and/or quinolinic acid, which induces excitotoxicity by the activation of an intracellular cascade responsible for neuronal dysfunctions and death (Ratnakumari et al., 1995a). Although NMDA receptors may be down-regulated, a certain level of persistent excitotoxicity may continue and lead to the neuronal loss observed in patients with congenital hyperammonemia (Rao and Qureshi, 1999). Interestingly, NMDA receptor antagonists MK-801 and 2-amino-5-phosphonovaleric acid (APV) improve neuronal survival in primary cortical neurons from newborn rats treated with $\mathrm{NH}_{4} \mathrm{Cl}$ (Fig. 2) (Klejman et al., 2005). Moreover, APV diminishes the impairment of long term potentiation (LTP) by $\mathrm{NH}^{+}$exposure in rat hippocampal slices (Izumi et al., 2005).

\subsection{2: Cholinergic system}

A significant loss of forebrain cholinergic neurons was observed in spf mice (Ratnakumari et al., 1994b). Similarly in aggregating brain cell 3D cultures, data showed that early in development cholinergic neurons were impaired by $\mathrm{NH}_{4} \mathrm{Cl}$ treatment (Braissant et al., 2002). A developmental study in spf mice showed that choline acetyltransferase (ChAT) activity level starts to decrease immediately after weaning and reaches significantly lower level in adult mice (Ratnakumari et al., 1995b). Moreover, subsequent studies of muscarinic cholinergic M1 (postsynaptic) and M2 (presynaptic) receptors revealed an up to 54\% increase of the M1 receptor and a concomitant decrease by up to $60 \%$ of the M2 receptor in spf mice (Ratnakumari et al., 1996a). Increase in the M1 post-synaptic receptors could be due to an upregulation in response to the loss of cholinergic presynaptic neurons (Michalak and Butterworth, 1997). Together, these results points towards a severe impairment of cholinergic system by hyperammonemia. As cholinergic system plays a crucial role in memory and other cognitive functions, this impairment under hyperammonemia may be responsible for 
cognitive dysfunctions observed in patients with urea cycles disorders and in spf mice (Russell, 1996).

\subsection{3: Serotoninergic system}

Tryptophan (precursor for serotonin) and 5-hydroxyindoleacetic acid (metabolite of serotonin) are enhanced in spf mice brain and in CSF of children with congenital hyperammonemia (Bachmann and Colombo, 1984; Hyman et al., 1987). Moreover, receptor binding studies in spf mice reveal a significant loss of $5 \mathrm{HT}_{2}$ receptor and a concomitant increase in $5 \mathrm{HT}_{1 \mathrm{~A}}$ receptor (Robinson et al., 1992a). These data demonstrate alterations of the serotoninergic system in congenital hyperammonemia that may be involved in anorexia and sleep disturbance observed in children with urea cycle disorders (Hyman et al., 1986).

\section{3: Cerebral energy deficit}

In the brain of spf mice, the ATP concentration is decreased (Ratnakumari et al., 1992), while a significant decrease in cytochrome $\mathrm{C}$ oxidase expression and activity is observed, suggesting that reduction in ATP levels could be due to a reduction of the activity of the electron transport chain enzymes (Fig. 2) (Rao et al., 1997). It has also been suggested that the deficit in brain energy metabolites in hyperammonemia may be due to inhibition of the TCA cycle, especially at the level of $\alpha$-ketoglutarate dehydrogenase (Fig. 2) (Lai and Cooper, 1986). However, it has been shown that ATP depletion alone is not enough to induce neuronal death (Marcaida et al., 1995).

The creatine / phosphocreatine / creatine kinase system is essential for the buffering and transport of high-energy phosphates (Wyss and Kaddurah-Daouk, 2000), and the mammalian brain is able of its own creatine synthesis both in adulthood and during development (Braissant et al., 2001b; Braissant et al., 2005; Braissant et al., 2007). Creatine is decreased in 
the brain of $s p f$ mice (Ratnakumari et al., 1996b). In brain cell 3D primary cultures exposed to $\mathrm{NH}_{4} \mathrm{Cl}$, we have shown that axonal growth is impaired and that creatine and phosphocreatine are decreased (Fig. 3) (Braissant et al., 2002; Braissant et al., 2006). These studies support the hypothesis of an energy deficit induced by $\mathrm{NH}_{4}{ }^{+}$exposure. Recent data demonstrate that $\mathrm{NH}_{4}{ }^{+}$ exposure generates a secondary creatine deficiency in brain cells, through disturbances of creatine transport and synthesis pathway (Braissant, Cagnon, Monnet-Tschudi, Speer, Wallimann, Honegger and Henry, submitted for publication). Interestingly, axonal growth is protected under $\mathrm{NH}_{4}{ }^{+}$exposure by creatine co-treatment, in a glial cell-dependent manner (Braissant et al., 2002) (see also below 4.7: impairment of axonal and dendritic growth). The protective potential of creatine has been illustrated in numerous models of neurodegeneration (Fig. 2 and 3) (Brewer and Wallimann, 2000; Wilken et al., 2000).

Another agent, acetyl-L-carnitine, has also been proposed for the recovery of cerebral energy deficits induced by $\mathrm{NH}_{4}{ }^{+}$. The main role of carnitine is to shuttle acyl-CoA derived from fatty acids across the inner mitochondrial membrane. Once inside the mitochondria, the acyl-CoA molecule undergoes beta-oxidation producing acetyl-CoA that can enter the Krebs cycle leading to the production of ATP. It has been shown that acetyl-L-carnitine is able to enhance the restoration of ATP and phosphocreatine levels in a model of ischemia (Aureli et al., 1994). A treatment of pregnant spf mice with acetyl-L-carnitine, starting from day 1 of conception, resulted in a significant restoration of ChAT activity levels in some brain regions of the $s p f / Y$ offspring, suggesting that acetyl-L-carnitine may be neuroprotective in $\mathrm{NH}_{4}{ }^{+}$induced toxicity (Ratnakumari et al., 1995b). It was suggested that this protective effect may be due to the restoration of the cytochrome C oxidase activity in spf mice (Rao et al., 1997). Aside from being an essential component of fatty acid metabolism, acetyl-L-carnitine is also a free-radical scavenger and may contribute to the protection of cells against oxidative stress (Zanelli et al., 2005). 


\section{4: Alteration of nitric oxide synthesis}

NO is synthesized by nitric oxide synthase (NOS) from the unique precursor L-arginine. NOS, when expressed in concert with ASS and ASL, constitutes the citrulline-NO cycle, which allows the recycling of the by-product of NO synthesis, citrulline, to arginine (Fig. 2) (Morris, 2004). ASS and ASL can be found in almost every cell, including in the CNS, albeit most of the time at lower levels than when expressed for the urea cycle in hepatocytes (Wakabayashi, 1998; Braissant et al., 1999b; Husson et al., 2003). It has been suggested that to assure their specific needs in NO synthesis, brain cells depend on (i) arginine supply from periphery and between brain cells with the implication of the various cationic amino acid transporters (CATs) and other cationic amino acid carriers such as $\mathrm{y}^{+} \mathrm{L}$-associated transporters ( $\mathrm{y}^{+}$LATs), (ii) the regulation of arginine levels by arginase 2, and (iii) the recycling of citrulline to arginine by ASS and ASL, sometimes in cells different from the ones synthesizing NO (Braissant et al., 1999a; Wiesinger, 2001; Braissant et al., 2001a; Braissant, 2007).

In postsynaptic neurons, NO is formed following activation of glutamate receptors, mainly of the NMDA subtype. After this activation, $\mathrm{Ca}^{2+}$ is transiently increased in the cytosol and forms a complex with calmodulin that binds to and activates constitutive neuronal NOS (nNOS or NOS1). This leads to an increased production of NO, which in turn activates soluble guanylate cyclase resulting in increased concentration of cGMP. This glutamate-NOcGMP pathway modulates important cerebral processes such as intercellular communication and LTP (Rodrigo and Felipo, 2006). As NMDA receptors are activated by $\mathrm{NH}_{4}{ }^{+}$exposure, it suggests that hyperammonemia can activate nNOS and stimulate NO synthesis in neurons (Fig. 2). It has been shown that treatment of primary cultures of cortical neurons with $\mathrm{NH}_{4}{ }^{+}$ 
results in an increase of the cGMP level in response to SNAP, a NO-generating agent (Rodrigo et al., 2005). In contrast, in primary cultures of cerebellar neurons exposed to $\mathrm{NH}_{4}{ }^{+}$, the formation of cGMP is reduced following SNAP addition (Rodrigo et al., 2005). The mechanism by which $\mathrm{NH}_{4}{ }^{+}$can lead to opposite effects in cerebellum and cerebral cortex is not understood by now.

In glial cells, $\mathrm{NO}$ is synthesized after the transcriptional induction of a $\mathrm{Ca}^{2+}$-independent inducible NOS isoform (iNOS or NOS2). In contrast to nNOS-derived NO formation which occurs transiently, iNOS activity can generate high concentrations of NO (for review see Moncada and Bolanos, 2006). In primary cultures of astrocytes, $\mathrm{NH}_{4}{ }^{+}$induces iNOS expression and enhances NO synthesis (Schliess et al., 2002). It is known that elevated NO concentrations can interact with superoxide anion, leading to the formation of the highly toxic peroxynitrites. Thus, the excessive formation of $\mathrm{NO}$ by astrocytes induced by $\mathrm{NH}_{4}{ }^{+}$may induce peroxynitrites in the neighboring neurons, leading to neuronal death (Fig. 2). Moreover, it has been suggested that $\mathrm{NH}_{4}{ }^{+}$-induced production of NO could inhibit GS, the only $\mathrm{NH}_{4}^{+}$detoxification pathway in the brain, which might thus even worsen the consequences of hyperammonemia on CNS (Fig. 2) (Rose and Felipo, 2005). This increase in NOS activity and NO synthesis under $\mathrm{NH}_{4}{ }^{+}$exposure is coherent with our observation in brain cell 3D cultures exposed to $\mathrm{NH}_{4} \mathrm{Cl}$, which increase their arginine content and induce the astrocytic expression of ASS and ASL, thus stimulating the citrulline-NO cycle (Braissant et al., 1999b; Bachmann et al., 2004).

NO synthesis has also been studied in vivo. The NOS activity and NO synthesis have been shown decreased in the brain of spf mice (Ratnakumari et al., 1996b). Similarly, in patients with OTC deficiency, plasmatic and urinary NO metabolites (as markers for NO synthesis) were shown below the normal range showing a decrease of NO synthesis (Nagasaka et al., 
2004). This is in accordance with the decrease in arginine (precursor for NO) content observed under urea cycle deficiencies. In contrast, experimental models with adequate arginine supplementation show opposite effects on NO synthesis under hyperammonemia. For instance, nNOS expression is increased, both at mRNA and protein levels, in the hyperammonemic brain of portacaval shunted rats (Rao, 2002), and NO production is increased in the brain of rats exposed to $\mathrm{NH}_{4}{ }^{+}$-acetate (Kosenko et al., 1998).

\section{5: Oxidative stress}

Oxidative stress results from an imbalance between formation of free radicals and their neutralization by antioxidants. Free radicals are highly reactive, unstable molecules that have an unpaired electron in their outer shell. Free radicals are generally reactive oxygen or nitrogen species such as hydrogen peroxide, hydroxyl radical, nitric oxide, peroxynitrite and superoxide anion. They react with various cellular components leading to DNA damage, mitochondrial malfunction, cell membrane damage and eventually cell death.

Increased superoxide production and decreased activities of antioxidant enzymes such as glutathione peroxidase, superoxide dismutase and catalase, were observed in brain rats injected with $\mathrm{NH}_{4}{ }^{+}$-acetate (Kosenko et al., 1997; Kosenko et al., 1998). In this model, inhibition of NOS by nitroarginine, or the use of NMDA receptor antagonists, prevent those changes suggesting that $\mathrm{NH}_{4}{ }^{+}$-induced oxidative stress is due to the increased formation of NO as a consequence of excessive activation of NMDA receptors (Fig. 2) (Kosenko et al., 1998; Kosenko et al., 1999). Similarly, the production of free radicals is enhanced in a dosedependent manner in primary cultures of astrocytes exposed to $\mathrm{NH}_{4}{ }^{+}$(Murthy et al., 2001; Reinehr et al., 2007).

\section{6: Induction of mitochondrial permeability transition}


The mitochondrial permeability transition (MPT) is a sudden increase of the inner mitochondrial membrane permeability to ions and solutes, which causes disruption of mitochondrial inner membrane potential (maintained by the pumping out of protons by the electron transport chain) and diffusion of solutes down their concentration gradient. This leads to defective oxidative phosphorylation, cessation of ATP synthesis and the generation of reactive oxygen species. MPT is one of the major causes of cell death in a variety of conditions (Kroemer et al., 2007).

In primary cultures of astrocytes, $\mathrm{NH}_{4}{ }^{+}$induces a collapse of the mitochondrial inner membrane potential that is associated with enhanced mitochondrial permeability (Fig. 2) (Bai et al., 2001). Similar treatments of cultured neurons failed to produce a dissipation of the mitochondrial inner membrane potential, suggesting that $\mathrm{NH}_{4}{ }^{+}$-induced neuronal death may not be mediated by MPT (Bai et al., 2001). It has been shown that creatine is able to inhibit MPT pore opening (O'Gorman et al., 1997; Dolder et al., 2003). As MPT is causally related to cell death and is induced by $\mathrm{NH}_{4}{ }^{+}$treatment in glial cells, creatine may represent a potential strategy for the CNS protection against $\mathrm{NH}_{4}{ }^{+}$toxicity (Fig. 2 and 3).

\section{7: Impairment of axonal and dendritic growth}

Cortical atrophy, ventricular enlargement, or gray and white matter hypodensities are found in the developing brain of hyperammonemic neonates and infants (Msall et al., 1984; Harding et al., 1984; Call et al., 1984; Filloux et al., 1986; Dolman et al., 1988; Uchino et al., 1998; Wakamoto et al., 1999; Majoie et al., 2004). These clinical findings are reminiscent of neuronal fiber loss or defects of neurite outgrowth (Fig. 3). A significant loss of medium spiny neurons and increased numbers of reactive oligodendroglia and microglia in the striatum are also observed (Robinson et al., 1995). Moreover in spf mice, analysis of the 
dendritic tree of layer $\mathrm{V}$ pyramidal cells in frontoparietal cortex revealed a significant decrease in both the complexity of the dendritic arbor and in dendritic terminal spine density (Hopkins et al., 1998). The alteration of dendritic arbor development under hyperammonemia might be triggered by dysregulations of dendritic cytoskeletal elements. Felipo et al. showed for instance that hyperammonemic rats present a decreased phosphorylation of the dendritic protein microtubule associated protein 2 (MAP-2), in parallel with an increase of MAP-2 binding to microtubules (Felipo et al., 1993). Using aggregating brain cell 3D primary cultures prepared from fetal rat telencephalon, we have shown that $\mathrm{NH}_{4}{ }^{+}$exposure inhibits axonal growth, together with a decreased of NFM expression and phosphorylation (Braissant et al., 2002; Braissant, 2006). We further showed that the inhibition of axonal growth is accompanied by a decrease of creatine in the developing brain cells, and that creatine cotreatment under $\mathrm{NH}_{4}{ }^{+}$exposure can protect axonal growth and restore NFM expression and phosphorylation in a glial cell-dependent manner (Fig. 3) (Braissant et al., 2002).

\section{8: Disturbances in signaling transduction pathways}

Recent works suggest that disturbances in upstream cell-signaling pathways may be responsible for numerous downstream mechanisms of developmental defaults or cell death in the brain (Mielke and Herdegen, 2000; Stanciu et al., 2000). Among these, mitogen-activated protein kinases (MAPKs) are good candidates for mediating upstream signals that lead to hyperammonemia-induced brain cell injury. MAPKs are part of an evolutionarily conserved mechanism that transduces extracellular signals, stress and injury to intracellular responses that balance survival, differentiation and death of the cell (Xia et al., 1995). Recent studies have shown that Erk1/2, JNK1/2/3 and p38 ${ }^{\mathrm{MAPK}}$ are activated in astrocytes by $\mathrm{NH}_{4}{ }^{+}$(Schliess et al., 2002; Jayakumar et al., 2006). Early phosphorylation of Erk1/2 and p38 ${ }^{\mathrm{MAPK}}$ seems 
responsible for $\mathrm{NH}_{4}{ }^{+}$-induced astrocyte swelling whereas early phosphorylation of JNK1/2/3 and $\mathrm{p} 38^{\mathrm{MAPK}}$ is involved in $\mathrm{NH}_{4}{ }^{+}$-induced inhibition of glutamate uptake in astrocytes (Schliess et al., 2002; Jayakumar et al., 2006). During CNS development, MAPKs are also involved in neuronal maturation and differentiation. In particular, Erk1/2 is involved in axonal and dendritic outgrowth, by regulating the phosphorylation state of cytoskeletal proteins such as neurofilaments (axons) and MAP-2 (dendrites), either directly or through activation of Cdk5 (Fig. 3) (Veeranna et al., 1998; Harada et al., 2001). MAPKs are dysregulated in NMDA excitotoxicity and cerebral ischemia (Borsello et al., 2003a; Borsello et al., 2003b), and have been proposed as targets in therapeutic approaches to counteract these CNS pathophysiological conditions (Mehta et al., 2007). Although activation levels of MAPKs have not been studied yet in neurons under $\mathrm{NH}_{4}{ }^{+}$-exposure, the manipulation of MAPK pathways may represent a novel therapeutic target for protecting the CNS development of pediatric patients with hyperammonemia from the deleterious effects of $\mathrm{NH}_{4}^{+}$.

\section{9: Impairment of cognitive performance}

In line with clinical data showing that patients with urea cycle deficits often show mental retardation, several studies demonstrate that hyperammonemia induces impairment of cognitive performance in animal models. Using two learning tasks (passive avoidance test and Morris-type water maze), D’Hooge et al. have demonstrated deficits in cognitive functions in spf mice during episodes of hyperammonemia (D'Hooge et al., 2000). Aguilar et al. compared the cognitive performance of rats prenatally and neonatally exposed to $\mathrm{NH}_{4}{ }^{+}$, with adult rats exposed for 15 days (Aguilar et al., 2000). With respect to passive avoidance behavior, adult hyperammonemia had no effect whereas the pre/neonatal hyperammonemia produced a clear increase in the step-through latency, suggesting that $\mathrm{NH}_{4}{ }^{+}$exposure during prenatal and neonatal period impairs memory or conditioned learning of the animals. Moreover, LTP, a 
phenomenon that is considered to be the molecular basis for some forms of memory and learning, is markedly reduced in hippocampal slices from rats prenatally and neonatally exposed to ammonia (Munoz et al., 2000). The impairment of LTP in hyperammonemia could be responsible for at least some of the cognitive alterations found in hyperammonemic rats and spf mice and could be involved in the origin of the mental retardation in infants and children with congenital hyperammonemia.

\section{5: Conclusion and perspectives for neuroprotection against ammonium toxicity on the developing CNS}

In conclusion, hyperammonemia is associated with neuronal cell loss and cerebral atrophy that lead to mental retardation and cerebral palsy in pediatric patients. These toxic effects of $\mathrm{NH}_{4}{ }^{+}$are specific to the developing brain, as neuronal damages are not observed in the brain of adult patients with hyperammonemia due to liver failure. While, for a long time, the mechanisms of toxic effects of $\mathrm{NH}_{4}{ }^{+}$on the developing brain were poorly understood, several recent clues have been provided by different models of hyperammonemia such as spf mice, rats treated prenatally and neonatally with $\mathrm{NH}_{4}{ }^{+}$-acetate, as well as with brain cell 3D primary cultures treated with $\mathrm{NH}_{4} \mathrm{Cl}$ during the development phase. Alterations in amino acids synthesis, in neurotransmitter functions, in nitric oxide metabolism as well as in cerebral energy, induction of oxidative stress and MPT have been observed, and may be responsible for neuronal cell death and axonal growth inhibition. Recent studies suggest also disturbances in signaling transduction pathways. Some neuroprotective strategies have been suggested by experiments in the different models, including the use of NMDA receptor antagonists, NOS inhibitors, creatine and acetyl-L-carnitine (Fig. 2 and 3). 
As illustrated in this review, unraveling new therapeutic targets to protect the brain of hyperammonemic neonates and infants will require experimental approaches focusing on the developing CNS in its cellular complexity, with neurons and glial cells interacting together. Thus, future studies may focus not only on the intracellular (e.g. MAPKs or others), but also on the extracellular signaling pathways disturbed between developing brain cells under $\mathrm{NH}_{4}{ }^{+}$ exposure. 


\section{Acknowledgments}

This work was supported by the Swiss National Science Foundation, grants $\mathrm{n}^{\circ} 3100$ 63892.00, 3100A0-100778 and 3100A0-116859.

\section{References}

Aguilar, M.A., Minarro, J., Felipo, V., 2000. Chronic moderate hyperammonemia impairs active and passive avoidance behavior and conditional discrimination learning in rats. Exp. Neurol. 161, 704-713.

Aureli, T., Miccheli, A., Di Cocco, M.E., Ghirardi, O., Giuliani, A., Ramacci, M.T., Conti, F., 1994. Effect of acetyl-L-carnitine on recovery of brain phosphorus metabolites and lactic acid level during reperfusion after cerebral ischemia in the rat--study by 13P- and 1H-NMR spectroscopy. Brain Res. 643, 92-99.

Azorin, I., Minana, M.D., Felipo, V., Grisolia, S., 1989. A simple animal model of hyperammonemia. Hepatology. 10, 311-314.

Bachmann, C., Colombo, J.P., 1984. Increase of tryptophan and 5-hydroxyindole acetic acid in the brain of ornithine carbamoyltransferase deficient sparse-fur mice. Pediatr. Res. $18,372-375$.

Bachmann, C., 1992. Ornithine carbamoyl transferase deficiency: findings, models and problems. J. Inherit. Metab Dis. 15, 578-591.

Bachmann, C., 2002. Mechanisms of hyperammonemia. Clin. Chem. Lab Med. 40, 653-662.

Bachmann, C., 2003. Outcome and survival of 88 patients with urea cycle disorders: a retrospective evaluation. Eur. J. Pediatr. 162, 410-416. 
Bachmann, C., Braissant, O., Villard, A.M., Boulat, O., Henry, H., 2004. Ammonia toxicity to the brain and creatine. Mol. Genet. Metab. 81 Suppl 1, S52-S57.

Bai, G., Rama Rao, K.V., Murthy, C.R., Panickar, K.S., Jayakumar, A.R., Norenberg, M.D., 2001. Ammonia induces the mitochondrial permeability transition in primary cultures of rat astrocytes. J. Neurosci. Res. 66, 981-991.

Batshaw, M.L., Robinson, M.B., Hyland, K., Djali, S., Heyes, M.P., 1993. Quinolinic acid in children with congenital hyperammonemia. Ann. Neurol. 34, 676-681.

Batshaw, M.L., MacArthur, R.B., Tuchman, M., 2001. Alternative pathway therapy for urea cycle disorders: twenty years later. J. Pediatr. 138, S46-S54.

Berry, G.T., Steiner, R.D., 2001. Long-term management of patients with urea cycle disorders. J. Pediatr. 138, S56-S60.

Borsello, T., Clarke, P.G., Hirt, L., Vercelli, A., Repici, M., Schorderet, D.F., Bogousslavsky, J., Bonny, C., 2003a. A peptide inhibitor of c-Jun N-terminal kinase protects against excitotoxicity and cerebral ischemia. Nat. Med. 9, 1180-1186.

Borsello, T., Croquelois, K., Hornung, J.P., Clarke, P.G., 2003b. N-methyl-d-aspartatetriggered neuronal death in organotypic hippocampal cultures is endocytic, autophagic and mediated by the c-Jun N-terminal kinase pathway. Eur. J. Neurosci. 18, 473-485.

Braissant, O., Gotoh, T., Loup, M., Mori, M., Bachmann, C., 1999a. L-arginine uptake, the citrulline-NO cycle and arginase II in the rat brain: an in situ hybridization study. Brain Res. Mol. Brain Res. 70, 231-241.

Braissant, O., Honegger, P., Loup, M., Iwase, K., Takiguchi, M., Bachmann, C., 1999b. Hyperammonemia: regulation of argininosuccinate synthetase and argininosuccinate 
lyase genes in aggregating cell cultures of fetal rat brain. Neuroscience Letters. 266, 8992.

Braissant, O., Gotoh, T., Loup, M., Mori, M., Bachmann, C., 2001a. Differential expression of the cationic amino acid transporter 2(B) in the adult rat brain. Brain Res. Mol. Brain Res. 91, 189-195.

Braissant, O., Henry, H., Loup, M., Eilers, B., Bachmann, C., 2001b. Endogenous synthesis and transport of creatine in the rat brain: an in situ hybridization study. Brain Res. Mol. Brain Res. 86, 193-201.

Braissant, O., Henry, H., Villard, A.M., Zurich, M.G., Loup, M., Eilers, B., Parlascino, G., Matter, E., Boulat, O., Honegger, P., Bachmann, C., 2002. Ammonium-induced impairment of axonal growth is prevented through glial creatine. J Neurosci. 22, 98109820.

Braissant, O., Henry, H., Villard, A.M., Speer, O., Wallimann, T., Bachmann, C., 2005. Creatine synthesis and transport during rat embryogenesis: spatiotemporal expression of AGAT, GAMT and CT1. BMC. Dev. Biol. 5, 9.

Braissant, O., Henry, H., Cagnon, L., Honegger, P., Bachmann, C. 2006. Glial mechanisms of axonal growth protection from ammonia. In Hepatic Encephalopathy and Nitrogen Metabolism. Haussinger D., ed. Springer. pp 124-133.

Braissant, O. 2006. Neurofilament proteins in brain diseases. In New Research on Neurofilament Proteins. Arlen RK, ed. Nova Science Publishers Inc. New York, pp 25-51. 
Braissant, O. 2007. Pathways depending on urea cycle intermediates. In Pathophysiology and Management of Hyperammonemia. Bachmann C, Häberle J, Koch HG, Leonard J, eds. SPS Publications. Heilbronn, Germany, pp in press.

Braissant, O., Bachmann, C., Henry, H., 2007. Expression and function of AGAT, GAMT and CT1 in the mammalian brain. Subcell. Biochem. 46, in press.

Brewer, G.J., Wallimann, T.W., 2000. Protective effect of the energy precursor creatine against toxicity of glutamate and beta-amyloid in rat hippocampal neurons. J. Neurochem. 74, 1968-1978.

Brusilow, S.W., Valle, D.L., Batshaw, M., 1979. New pathways of nitrogen excretion in inborn errors of urea synthesis. Lancet. 2, 452-454.

Brusilow, S.W., Maestri, N.E., 1996. Urea cycle disorders: diagnosis, pathophysiology, and therapy. Adv. Pediatr. 43, 127-170.

Brusilow, S.W., Horwich, A.L., 2001. Urea cycles enzymes. The metabolic and molecular bases of inherited disease. C. R. Scriver, A. L. Beaudet, W. S. Sly, and D. Valle, eds (New York: McGraw-Hill).1909-1963.

Butterworth, R.F., 1998. Effects of hyperammonaemia on brain function. J. Inherit. Metab Dis. 21 Suppl 1, 6-20.

Butterworth, R.F., 2003. Hepatic encephalopathy. Alcohol Res. Health. 27, 240-246.

Call, G., Seay, A.R., Sherry, R., Qureshi, I.A., 1984. Clinical features of carbamyl phosphate synthetase-I deficiency in an adult. Ann. Neurol. 16, 90-93. 
Chan, H., Hazell, A.S., Desjardins, P., Butterworth, R.F., 2000. Effects of ammonia on glutamate transporter (GLAST) protein and mRNA in cultured rat cortical astrocytes. Neurochemistry International. 37, 243-248.

Chepkova, A.N., Sergeeva, O.A., Haas, H.L., 2006. Taurine rescues hippocampal long-term potentiation from ammonia-induced impairment. Neurobiol. Dis. 23, 512-521.

Choi, J.H., Kim, H., Yoo, H.W., 2006. Two cases of citrullinaemia presenting with stroke. J. Inherit. Metab Dis. 29, 182-183.

Connelly, A., Cross, J.H., Gadian, D.G., Hunter, J.V., Kirkham, F.J., Leonard, J.V., 1993. Magnetic resonance spectroscopy shows increased brain glutamine in ornithine carbamoyl transferase deficiency. Pediatr. Res. 33, 77-81.

Cordoba, J., Blei, A.T., 1996. Brain edema and hepatic encephalopathy. Semin. Liver Dis. 16, 271-280.

Curis, E., Nicolis, I., Moinard, C., Osowska, S., Zerrouk, N., Benazeth, S., Cynober, L., 2005. Almost all about citrulline in mammals. Amino. Acids. 29, 177-205.

D'Hooge, R., Marescau, B., Qureshi, I.A., De Deyn, P.P., 2000. Impaired cognitive performance in ornithine transcarbamylase-deficient mice on arginine-free diet. Brain Res. 876, 1-9.

de Grauw, T.J., Smit, L.M., Brockstedt, M., Meijer, Y., vd Klei-von, M.J., Jakobs, C., 1990. Acute hemiparesis as the presenting sign in a heterozygote for ornithine transcarbamylase deficiency. Neuropediatrics. 21, 133-135.

de Knegt, R.J., Schalm, S.W., van der Rijt, C.C., Fekkes, D., Dalm, E., Hekking-Weyma, I., 1994. Extracellular brain glutamate during acute liver failure and during acute 
hyperammonemia simulating acute liver failure: an experimental study based on in vivo brain dialysis. J. Hepatol. 20, 19-26.

Deignan, J.L., Livesay, J.C., Yoo, P.K., Goodman, S.I., O'Brien, W.E., Iyer, R.K., Cederbaum, S.D., Grody, W.W., 2006. Ornithine deficiency in the arginase double knockout mouse. Mol. Genet. Metab. 89, 87-96.

DeMars, R., LeVan, S.L., Trend, B.L., Russell, L.B., 1976. Abnormal ornithine carbamoyltransferase in mice having the sparse-fur mutation. Proc. Natl. Acad. Sci. U. S. A. 73, 1693-1697.

Dolder, M., Walzel, B., Speer, O., Schlattner, U., Wallimann, T., 2003. Inhibition of the mitochondrial permeability transition by creatine kinase substrates. Requirement for microcompartmentation. J. Biol. Chem. 278, 17760-17766.

Dolman, C.L., Clasen, R.A., Dorovini-Zis, K., 1988. Severe cerebral damage in ornithine transcarbamylase deficiency. Clin. Neuropathol. 7, 10-15.

Donn, S.M., Banagale, R.C., 1984. Neonatal Hyperammonemia. Ped. Rev. 5, 203-208.

Doolittle, D.P., Hulbert, L.L., Cordy, C., 1974. A new allele of the sparse fur gene in the mouse. J. Hered. 65, 194-195.

Doyle A, Griffiths JB, Newel DG (1994) Cell and tissue culture: Laboratory procedures. Chichester: Wiley.

Enns, G.M., Berry, S.A., Berry, G.T., Rhead, W.J., Brusilow, S.W., Hamosh, A., 2007. Survival after treatment with phenylacetate and benzoate for urea-cycle disorders. N. Engl. J. Med. 356, 2282-2292. 
Feillet, F., Leonard, J.V., 1998. Alternative pathway therapy for urea cycle disorders. J. Inherit. Metab Dis. 21 Suppl 1, 101-111.

Felipo, V., Grau, E., Minana, M.D., Grisolia, S., 1993. Activation of NMDA receptor mediates the toxicity of ammonia and the effects of ammonia on the microtubuleassociated protein MAP-2. Adv. Exp. Med. Biol. 341, 83-93.

Felipo, V., Butterworth, R.F., 2002. Neurobiology of ammonia. Prog Neurobiol. 67, 259-279.

Filloux, F., Townsend, J.J., Leonard, C., 1986. Ornithine transcarbamylase deficiency: neuropathologic changes acquired in utero. J. Pediatr. 108, 942-945.

Flint Beal, M., Martin, J.B. 1998. Major complications of cirrhosis. In Harrison's principles of internal medicine. Fauci AS, Braunwald E, Isselbacher KJ, Wilson JD, Martin JB, Kasper DL, Hauser SL, Longo DL, eds. McGraw-Hill. New-York, pp 2451-2457.

Gropman, A.L., Batshaw, M.L., 2004. Cognitive outcome in urea cycle disorders. Mol. Genet. Metab. 81, S58-S62.

Gushiken, T., Yoshimura, N., Saheki, T., 1985. Transient hyperammonemia during aging in ornithine transcarbamylase-deficient, sparse-fur mice. Biochem. Int. 11, 637-643.

Harada, E., Nishiyori, A., Tokunaga, Y., Watanabe, Y., Kuriya, N., Kumashiro, R., Kuno, T., Kuromaru, R., Hirose, S., Ichikawa, K., Yoshino, M., 2006. Late-onset ornithine transcarbamylase deficiency in male patients: prognostic factors and characteristics of plasma amino acid profile. Pediatr. Int. 48, 105-111.

Harada, T., Morooka, T., Ogawa, S., Nishida, E., 2001. ERK induces p35, a neuron-specific activator of Cdk5, through induction of Egr1. Nat. Cell Biol. 3, 453-459. 
Harding, B.N., Leonard, J.V., Erdohazi, M., 1984. Ornithine carbamoyl transferase deficiency: a neuropathological study. Eur. J. Pediatr. 141, 215-220.

Harding, B.N., Leonard, J.V., Erdohazi, M., 1991. Propionic acidaemia: a neuropathological study of two patients presenting in infancy. Neuropathol. Appl. Neurobiol. 17, 133-138.

Honegger, P., Monnet-Tschudi, F. 2001. Aggregating neural cell culture. In Protocols for neural cell culture. S.Fedoroff and Richardson e, ed. Totowa, NJ: Humana Press, Inc. pp 199-218.

Hopkins, K.J., McKean, J., Mervis, R.F., Oster-Granite, M.L., 1998. Dendritic alterations in cortical pyramidal cells in the sparse fur mouse. Brain Res. 797, 167-172.

Hopkins, K.J., Oster-Granite, M.L., 1998. Characterization of N-methyl-d-aspartate receptors in the hyperammonemic sparse fur mouse. Brain Res. 797, 209-217.

Husson, A., Brasse-Lagnel, C., Fairand, A., Renouf, S., Lavoinne, A., 2003. Argininosuccinate synthetase from the urea cycle to the citrulline-NO cycle. Eur. J. Biochem. 270, 1887-1899.

Hyman, S.L., Coyle, J.T., Parke, J.C., Porter, C., Thomas, G.H., Jankel, W., Batshaw, M.L., 1986. Anorexia and altered serotonin metabolism in a patient with argininosuccinic aciduria. J. Pediatr. 108, 705-709.

Hyman, S.L., Porter, C.A., Page, T.J., Iwata, B.A., Kissel, R., Batshaw, M.L., 1987. Behavior management of feeding disturbances in urea cycle and organic acid disorders. J. Pediatr. $111,558-562$. 
Inoue, I., Gushiken, T., Kobayashi, K., Saheki, T., 1987. Accumulation of large neutral amino acids in the brain of sparse-fur mice at hyperammonemic state. Biochem. Med. Metab Biol. 38, 378-386.

Iyer, R.K., Yoo, P.K., Kern, R.M., Rozengurt, N., Tsoa, R., O'Brien, W.E., Yu, H., Grody, W.W., Cederbaum, S.D., 2002. Mouse model for human arginase deficiency. Mol. Cell Biol. 22, 4491-4498.

Izumi, Y., Izumi, M., Matsukawa, M., Funatsu, M., Zorumski, C.F., 2005. Ammoniamediated LTP inhibition: effects of NMDA receptor antagonists and L-carnitine. Neurobiol. Dis. 20, 615-624.

Jayakumar, A.R., Panickar, K.S., Murthy, C., Norenberg, M.D., 2006. Oxidative stress and mitogen-activated protein kinase phosphorylation mediate ammonia-induced cell swelling and glutamate uptake inhibition in cultured astrocytes. J. Neurosci. 26, 47744784.

Kim, I.S., Ki, C.S., Kim, J.W., Lee, M., Jin, D.K., Lee, S.Y., 2006. Characterization of lateonset citrullinemia 1 in a Korean patient: confirmation by argininosuccinate synthetase gene mutation analysis. J. Biochem. Mol. Biol. 39, 400-405.

Klejman, A., Wegrzynowicz, M., Szatmari, E.M., Mioduszewska, B., Hetman, M., Albrecht, J., 2005. Mechanisms of ammonia-induced cell death in rat cortical neurons: roles of NMDA receptors and glutathione. Neurochem Int. 47, 51-57.

Kosenko, E., Kaminsky, Y., Kaminsky, A., Valencia, M., Lee, L., Hermenegildo, C., Felipo, V., 1997. Superoxide production and antioxidant enzymes in ammonia intoxication in rats. Free Radic. Res. 27, 637-644. 
Kosenko, E., Kaminsky, Y., Lopata, O., Muravyov, N., Kaminsky, A., Hermenegildo, C., Felipo, V., 1998. Nitroarginine, an inhibitor of nitric oxide synthase, prevents changes in superoxide radical and antioxidant enzymes induced by ammonia intoxication. Metab Brain Dis. 13, 29-41.

Kosenko, E., Kaminski, Y., Lopata, O., Muravyov, N., Felipo, V., 1999. Blocking NMDA receptors prevents the oxidative stress induced by acute ammonia intoxication. Free Radic. Biol. Med. 26, 1369-1374.

Kroemer, G., Galluzzi, L., Brenner, C., 2007. Mitochondrial membrane permeabilization in cell death. Physiol Rev. 87, 99-163.

Kurihara, A., Takanashi, J., Tomita, M., Kobayashi, K., Ogawa, A., Kanazawa, M., Yamamoto, S., Kohno, Y., 2003. Magnetic resonance imaging in late-onset ornithine transcarbamylase deficiency. Brain Dev. 25, 40-44.

Lai, J.C., Cooper, A.J., 1986. Brain alpha-ketoglutarate dehydrogenase complex: kinetic properties, regional distribution, and effects of inhibitors. J. Neurochem. 47, 1376-1386.

Lee, B., Goss, J., 2001. Long-term correction of urea cycle disorders. J. Pediatr. 138, S62S71.

Leonard, J.V., Morris, A.A.M., 2002. Urea cycle disorders. Sem. Neonat. 7, 27-35.

Leonard, J.V., Ward Platt, M.P., Morris, A.A., 2007. Hypothesis: proposals for the management of a neonate at risk of hyperammonaemia due to a urea cycle disorder. Eur. J. Pediatr. 
Majoie, C.B., Mourmans, J.M., Akkerman, E.M., Duran, M., Poll-The BT, 2004. Neonatal citrullinemia: comparison of conventional MR, diffusion-weighted, and diffusion tensor findings. Am. J. Neuroradiol. 25, 32-35.

Marcaida, G., Minana, M.D., Grisolia, S., Felipo, V., 1995. Lack of correlation between glutamate-induced depletion of ATP and neuronal death in primary cultures of cerebellum. Brain Res. 695, 146-150.

Marini, J.C., Lee, B., Garlick, P.J., 2006a. Ornithine restores ureagenesis capacity and mitigates hyperammonemia in Otc(spf-ash) mice. J. Nutr. 136, 1834-1838.

Marini, J.C., Lee, B., Garlick, P.J., 2006b. Reduced ornithine transcarbamylase activity does not impair ureagenesis in Otc(spf-ash) mice. J. Nutr. 136, 1017-1020.

Mehta, S.L., Manhas, N., Raghubir, R., 2007. Molecular targets in cerebral ischemia for developing novel therapeutics. Brain Res. Rev. 54, 34-66.

Michalak, A., Butterworth, R.F., 1997. Ornithine transcarbamylase deficiency: pathogenesis of the cerebral disorder and new prospects for therapy. Metab Brain Dis. 12, 171-182.

Mielke, K., Herdegen, T., 2000. JNK and p38 stresskinases -- degenerative effectors of signal-transduction-cascades in the nervous system. Prog. Neurobiol. 61, 45-60.

Moncada, S., Bolanos, J.P., 2006. Nitric oxide, cell bioenergetics and neurodegeneration. J. Neurochem. 97, 1676-1689.

Morris, S.M., 2002. Regulation of enzymes of the urea cycle and arginine metabolism. Annu. Rev. Nutr. 22, 87-105. 
Morris, S.M., 2004. Recent advances in arginine metabolism. Curr. Opin. Clin. Nutr. Metab Care. 7, 45-51.

Msall, M., Batshaw, M.L., Suss, R., Brusilow, S.W., Mellits, E.D., 1984. Neurologic outcome in children with inborn errors of urea synthesis. Outcome of urea-cycle enzymopathies. N. Engl. J Med. 310, 1500-1505.

Msall, M., Monahan, P.S., Chapanis, N., Batshaw, M.L., 1988. Cognitive development in children with inborn errors of urea synthesis. Acta Paediatr. Jpn. 30, 435-441.

Munoz, M.D., Monfort, P., Gaztelu, J.M., Felipo, V., 2000. Hyperammonemia impairs NMDA receptor-dependent long-term potentiation in the CA1 of rat hippocampus in vitro. Neurochem. Res. 25, 437-441.

Murthy, C.R., Rama Rao, K.V., Bai, G., Norenberg, M.D., 2001. Ammonia-induced production of free radicals in primary cultures of rat astrocytes. J. Neurosci. Res. 66, 282-288.

Nagasaka, H., Komatsu, H., Ohura, T., Sogo, T., Inui, A., Yorifuji, T., Murayama, K., Takayanagi, M., Kikuta, H., Kobayashi, K., 2004. Nitric oxide synthesis in ornithine transcarbamylase deficiency: Possible involvement of low no synthesis in clinical manifestations of urea cycle defect. J. Pediatr. 145, 259-262.

Nagata, N., Matsuda, I., Matsuura, T., Oyanagi, K., Tada, K., Narisawa, K., Kitagawa, T., Sakiyama, T., Yamashita, F., Yoshino, M., 1991. Retrospective survey of urea cycle disorders: Part 2. Neurological outcome in forty-nine Japanese patients with urea cycle enzymopathies. Am. J. Med. Genet. 40, 477-481. 
Nishie, M., Mori, F., Houzen, H., Yamaguchi, J., Jensen, P.H., Wakabayashi, K., 2006. Oligodendrocytes within astrocytes ("emperipolesis") in the cerebral white matter in hepatic and hypoglycemic encephalopathy. Neuropathology. 26, 62-65.

Norenberg, M.D., Rao, K.V., Jayakumar, A.R., 2005. Mechanisms of ammonia-induced astrocyte swelling. Metab Brain Dis. 20, 303-318.

O'Gorman, E., Beutner, G., Dolder, M., Koretsky, A.P., Brdiczka, D., Wallimann, T., 1997. The role of creatine kinase in inhibition of mitochondrial permeability transition. FEBS Lett. 414, 253-257.

Qureshi, I.A., Rao, K.V., 1997. Sparse-fur (spf) mouse as a model of hyperammonemia: alterations in the neurotransmitter systems. Adv. Exp. Med. Biol. 420, 143-158.

Rao, K.V., Mawal, Y.R., Qureshi, I.A., 1997. Progressive decrease of cerebral cytochrome C oxidase activity in sparse-fur mice: role of acetyl-L-carnitine in restoring the ammoniainduced cerebral energy depletion. Neurosci. Lett. 224, 83-86.

Rao, K.V., Qureshi, I.A., 1999. Reduction in the MK-801 binding sites of the NMDA subtype of glutamate receptor in a mouse model of congenital hyperammonemia: prevention by acetyl-L-carnitine. Neuropharmacology. 38, 383-394.

Rao, V.L., 2002. Nitric oxide in hepatic encephalopathy and hyperammonemia. Neurochem. Int. 41, 161-170.

Ratnakumari, L., Qureshi, I.A., Butterworth, R.F., 1992. Effects of congenital hyperammonemia on the cerebral and hepatic levels of the intermediates of energy metabolism in spf mice. Biochem Biophys. Res Commun. 184, 746-751. 
Ratnakumari, L., Qureshi, I.A., Butterworth, R.F., 1994a. Regional amino acid neurotransmitter changes in brains of spf/Y mice with congenital ornithine transcarbamylase deficiency. Metab Brain Dis. 9, 43-51.

Ratnakumari, L., Qureshi, I.A., Butterworth, R.F., 1994b. Evidence for cholinergic neuronal loss in brain in congenital ornithine transcarbamylase deficiency. Neurosci. Lett. 178, 63-65.

Ratnakumari, L., Qureshi, I.A., Butterworth, R.F., 1995a. Loss of [3H]MK801 binding sites in brain in congenital ornithine transcarbamylase deficiency. Metab Brain Dis. 10, 249255.

Ratnakumari, L., Qureshi, I.A., Maysinger, D., Butterworth, R.F., 1995b. Developmental deficiency of the cholinergic system in congenitally hyperammonemic spf mice: effect of acetyl-L-carnitine. J. Pharmacol. Exp. Ther. 274, 437-443.

Ratnakumari, L., Qureshi, I.A., Butterworth, R.F., 1996a. Central muscarinic cholinergic M1 and M2 receptor changes in congenital ornithine transcarbamylase deficiency. Pediatr. Res. 40, 25-28.

Ratnakumari, L., Qureshi, I.A., Butterworth, R.F., Marescau, B., De Deyn, P.P., 1996b. Arginine-related guanidino compounds and nitric oxide synthase in the brain of ornithine transcarbamylase deficient spf mutant mouse: effect of metabolic arginine deficiency. Neurosci. Lett. 215, 153-156.

Reid Sutton, V., Pan, Y., Davis, E.C., Craigen, W.J., 2003. A mouse model of argininosuccinic aciduria: biochemical characterization. Mol. Genet. Metab. 78, 11-16. 
Reinehr, R., Gorg, B., Becker, S., Qvartskhava, N., Bidmon, H.J., Selbach, O., Haas, H.L., Schliess, F., Haussinger, D., 2007. Hypoosmotic swelling and ammonia increase oxidative stress by NADPH oxidase in cultured astrocytes and vital brain slices. Glia. 55, 758-771.

Robinson, M.B., Anegawa, N.J., Gorry, E., Qureshi, I.A., Coyle, J.T., Lucki, I., Batshaw, M.L., 1992a. Brain serotonin2 and serotonin1A receptors are altered in the congenitally hyperammonemic sparse fur mouse. J. Neurochem. 58, 1016-1022.

Robinson, M.B., Heyes, M.P., Anegawa, N.J., Gorry, E., Djali, S., Mellits, E.D., Batshaw, M.L., 1992b. Quinolinate in brain and cerebrospinal fluid in rat models of congenital hyperammonemia. Pediatr. Res. 32, 483-488.

Robinson, M.B., Hopkins, K., Batshaw, M.L., McLaughlin, B.A., Heyes, M.P., Oster-Granite, M.L., 1995. Evidence of excitotoxicity in the brain of the ornithine carbamoyltransferase deficient sparse fur mouse. Brain Res. Dev. Brain Res. 90, 35-44.

Rodrigo, R., Erceg, S., Felipo, V., 2005. Neurons exposed to ammonia reproduce the differential alteration in nitric oxide modulation of guanylate cyclase in the cerebellum and cortex of patients with liver cirrhosis. Neurobiol. Dis. 19, 150-161.

Rodrigo, R., Felipo, V., 2006. Brain regional alterations in the modulation of the glutamatenitric oxide-cGMP pathway in liver cirrhosis. Role of hyperammonemia and cell types involved. Neurochem. Int. 48, 472-477.

Rose, C., Felipo, V., 2005. Limited capacity for ammonia removal by brain in chronic liver failure: potential role of nitric oxide. Metab Brain Dis. 20, 275-283. 
Rose, C., Kresse, W., Kettenmann, H., 2005. Acute insult of ammonia leads to calciumdependent glutamate release from cultured astrocytes, an effect of pH. J. Biol. Chem. 280, 20937-20944.

Russell, R.W., 1996. Continuing the search for cholinergic factors in cognitive dysfunction. Life Sci. 58, 1965-1970.

Salvi, S., Santorelli, F.M., Bertini, E., Boldrini, R., Meli, C., Donati, A., Burlina, A.B., Rizzo, C., Di Capua, M., Fariello, G., onisi-Vici, C., 2001. Clinical and molecular findings in hyperornithinemia-hyperammonemia-homocitrullinuria syndrome. Neurology. 57, 911914.

Scaglia, F., Zheng, Q., O'Brien, W.E., Henry, J., Rosenberger, J., Reeds, P., Lee, B., 2002. An integrated approach to the diagnosis and prospective management of partial ornithine transcarbamylase deficiency. Pediatrics. 109, 150-152.

Scaglia, F., Brunetti-Pierri, N., Kleppe, S., Marini, J., Carter, S., Garlick, P., Jahoor, F., O'Brien, W., Lee, B., 2004. Clinical consequences of urea cycle enzyme deficiencies and potential links to arginine and nitric oxide metabolism. J. Nutr. 134, 2775S-2782S.

Scaglia, F., Lee, B., 2006. Clinical, biochemical, and molecular spectrum of hyperargininemia due to arginase I deficiency. Am. J. Med. Genet. C. Semin. Med. Genet. 142, 113-120.

Schliess, F., Gorg, B., Fischer, R., Desjardins, P., Bidmon, H.J., Herrmann, A., Butterworth, R.F., Zilles, K., Haussinger, D., 2002. Ammonia induces MK-801-sensitive nitration and phosphorylation of protein tyrosine residues in rat astrocytes. FASEB J. 16, 739741. 
Schwarcz, R., Kohler, C., 1983. Differential vulnerability of central neurons of the rat to quinolinic acid. Neurosci. Lett. 38, 85-90.

Shih, V.E., 2007. Alternative-pathway therapy for hyperammonemia. N. Engl. J. Med. 356, 2321-2322.

Smith, W., Kishnani, P.S., Lee, B., Singh, R.H., Rhead, W.J., Sniderman, K.L., Smith, M., Summar, M., 2005. Urea cycle disorders: clinical presentation outside the newborn period. Crit Care Clin. 21, S9-17.

Song, G., Dhodda, V.K., Blei, A.T., Dempsey, R.J., Rao, V.L., 2002. GeneChip analysis shows altered mRNA expression of transcripts of neurotransmitter and signal transduction pathways in the cerebral cortex of portacaval shunted rats. J. Neurosci. Res. 68, 730-737.

Stanciu, M., Wang, Y., Kentor, R., Burke, N., Watkins, S., Kress, G., Reynolds, I., Klann, E., Angiolieri, M.R., Johnson, J.W., DeFranco, D.B., 2000. Persistent activation of ERK contributes to glutamate-induced oxidative toxicity in a neuronal cell line and primary cortical neuron cultures. J. Biol. Chem. 275, 12200-12206.

Summar, M., 2001. Current strategies for the management of neonatal urea cycle disorders. J. Pediatr. 138, S30-S39.

Takanashi, J., Kurihara, A., Tomita, M., Kanazawa, M., Yamamoto, S., Morita, F., Ikehira, H., Tanada, S., Kohno, Y., 2002. Distinctly abnormal brain metabolism in late-onset ornithine transcarbamylase deficiency. Neurology. 59, 210-214. 
Takanashi, J., Barkovich, A.J., Cheng, S.F., Kostiner, D., Baker, J.C., Packman, S., 2003a. Brain MR imaging in acute hyperammonemic encephalopathy arising from late-onset ornithine transcarbamylase deficiency. Am. J. Neuroradiol. 24, 390-393.

Takanashi, J., Barkovich, A.J., Cheng, S.F., Weisiger, K., Zlatunich, C.O., Mudge, C., Rosenthal, P., Tuchman, M., Packman, S., 2003b. Brain MR imaging in neonatal hyperammonemic encephalopathy resulting from proximal urea cycle disorders. Am. J. Neuroradiol. 24, 1184-1187.

Takeoka, M., Soman, T.B., Shih, V.E., Caviness, V.S., Krishnamoorthy, K.S., 2001. Carbamyl phosphate synthetase 1 deficiency: a destructive encephalopathy. Pediatr. Neurol. 24, 193-199.

Uchino, T., Endo, F., Matsuda, I., 1998. Neurodevelopmental outcome of long-term therapy of urea cycle disorders in Japan. J. Inherit. Metab Dis. 21 Suppl 1, 151-159.

Veeranna, Amin, N.D., Ahn, N.G., Jaffe, H., Winters, C.A., Grant, P., Pant, H.C., 1998. Mitogen-activated protein kinases (Erk1,2) phosphorylate Lys-Ser-Pro (KSP) repeats in neurofilament proteins NF-H and NF-M. J Neurosci. 18, 4008-4021.

Wakabayashi, Y., 1998. Tissue-selective expression of enzymes of arginine synthesis. Curr. Opin. Clin. Nutr. Metab Care. 1, 335-339.

Wakamoto, H., Manabe, K., Kobayashi, H., Hayashi, M., 1999. Subclinical portal-systemic encephalopathy in a child with congenital absence of the portal vein. Brain Dev. 21, 425-428.

Wiesinger, H., 2001. Arginine metabolism and the synthesis of nitric oxide in the nervous system. Prog. Neurobiol. 64, 365-391. 
Wilken, B., Ramirez, J.M., Probst, I., Richter, D.W., Hanefeld, F., 2000. Anoxic ATP depletion in neonatal mice brainstem is prevented by creatine supplementation. Arch. Dis. Child. Fetal Neonatal Ed. 82, F224-F227.

Wu, G., Morris, S.M., 1998. Arginine metabolism: nitric oxide and beyond. Biochem. J. 336, $1-17$.

Wyss, M., Kaddurah-Daouk, R., 2000. Creatine and creatinine metabolism. Physiol Rev. 80, 1107-1213.

Xia, Z., Dickens, M., Raingeaud, J., Davis, R.J., Greenberg, M.E., 1995. Opposing effects of ERK and JNK-p38 MAP kinases on apoptosis. Science. 270, 1326-1331.

Yamanouchi, H., Yokoo, H., Yuhara, Y., Maruyama, K., Sasaki, A., Hirato, J., Nakazato, Y., 2002. An autopsy case of ornithine transcarbamylase deficiency. Brain Dev. 24, 91-94.

Yu, H., Iyer, R.K., Kern, R.M., Rodriguez, W.I., Grody, W.W., Cederbaum, S.D., 2001. Expression of arginase isozymes in mouse brain. J. Neurosci. Res. 66, 406-422.

Zanelli, S.A., Solenski, N.J., Rosenthal, R.E., Fiskum, G., 2005. Mechanisms of ischemic neuroprotection by acetyl-L-carnitine. Ann N. Y. Acad Sci. 1053, 153-161. 


\section{Tables}

Table 1 : Causes of hyperammonemia in neonates and infants.

\section{Inherited disorders :}

\section{Urea cycle enzymes defects}

Carbamoylphosphate synthetase 1 (CPS-1) deficiency

Ornithine transcarbamoylase (OTC) deficiency

Arginosuccinate synthetase (ASS) deficiency (citrullinemia)

Arginosuccinate lyase (ASL) deficiency (arginosuccinic aciduria)

Arginase 1 deficiency

$\mathrm{N}$-acetylglutamate synthetase deficiency

\section{Defects in transporters of urea cycle intermediates}

Lysinuric protein intolerance $\left(\mathrm{y}^{+}\right.$-LAT1 deficiency)

Hyperammonemia-hyperornithinaemia-homocitrullinuria syndrome (ORNT1 deficiency)

Citrin (mitochondrial aspartate glutamate carrier) deficiency

\section{Organic acidemias}

Propionic acidemia

Methylmalonic acidemia

B-kethiolase deficiency

Isovaleric acidemia

\section{Fatty acid oxidation disorders}

Medium chain acyl-CoA dehydrogenase deficiency

Systemic carnitine deficiency

Long chain fatty acid oxidation defects

\section{Other inborn errors of metabolism}

Pyruvate carboxylase deficiency

Ornithine aminotransferase deficiency

$\Delta 1$-pyrroline-5-carboxylate synthase (P5CS) deficiency

\section{Acquired disorders :}

Transient hyperammonemia of the newborn

Herpes simplex systemic infection

Liver failure

Infection with urease positive bacteria

Portacaval shunt

Perinatal asphyxia 


\section{Figure legends}

Figure 1: Expression of the whole urea cycle in hepatocytes. Hyperammonemia occurs in case of deficiency in one of the six enzymes of the urea cycle (CPS-1 OTC, ASL, ASS, A-1 and NAGS; illustrated in red), or in ORNT1, citrin or pyruvate carboxylase. Other inborn errors of metabolism or acquired disorders generating hyperammonemia are listed in Table 1. A-1: arginase 1; AAT: aspartate aminotransferase; ASL: argininosuccinate lyase; ASS: argininosuccinate synthetase; CPS-1: carbamoylphosphate synthetase 1; NAG: Nacetylglutamate; NAGS: N-acetylglutamate synthetase; ORNT1: ornithine citrulline antiporter 1; OTC: ornithine transcarbamoylase; PC: pyruvate carboxylase.

Figure 2: Neurotoxicity of hyperammonemia. The toxic effects of $\mathrm{NH}_{4}{ }^{+}$exposure to neurons and astrocytes are illustrated in red. In particular, $\mathrm{NH}_{4}{ }^{+}$exposure generates oxidative stress, energy deficit and cell death in the central nervous system through disturbances of the nitric oxide pathways, inhibition of the TCA cycle, and opening of the mitochondrial permeability transition. The protective effects of creatine, acetyl-L-carnitine, NMDA antagonists and NOS inhibitors against $\mathrm{NH}_{4}{ }^{+}$toxicity to brain cells are illustrated in green. ASA: argininosuccinate; ASL: argininosuccinate lyase; ASS: argininosuccinate synthetase; GLAST: NA ${ }^{+}$-dependent glutamate / aspartate transporter; GS: glutamine synthase; iNOS: inductible nitric oxide synthase or NOS2; MPT: mitochondrial permeability transition; NMDA: N-methyl-D-aspartate; nNOS: neuronal nitric oxide synthase or NOS1; NO: nitric oxide;

Figure 3: Impairment of axonal growth by $\mathrm{NH}_{4}{ }^{+}$exposure. Irreversible effects of $\mathrm{NH}_{4}{ }^{+}$ exposure on the developing brain can occur through inhibition of axonal growth. The toxic 
effects of $\mathrm{NH}_{4}^{+}$exposure on neurofilament protein expression and phosphorylation, on axonal growth, on signaling pathways and on the creatine content of brain cells are illustrated in red. Neuroprotection strategies to counteract $\mathrm{NH}_{4}{ }^{+}$neurotoxicity are illustrated in green. A: Normal conditions of brain development. B: Hyperammonemia during brain development. MAPKs: mitogen activated protein kinase pathways; NFs: neurofilament proteins; P-NFs: phosphorylated neurofilaments. 


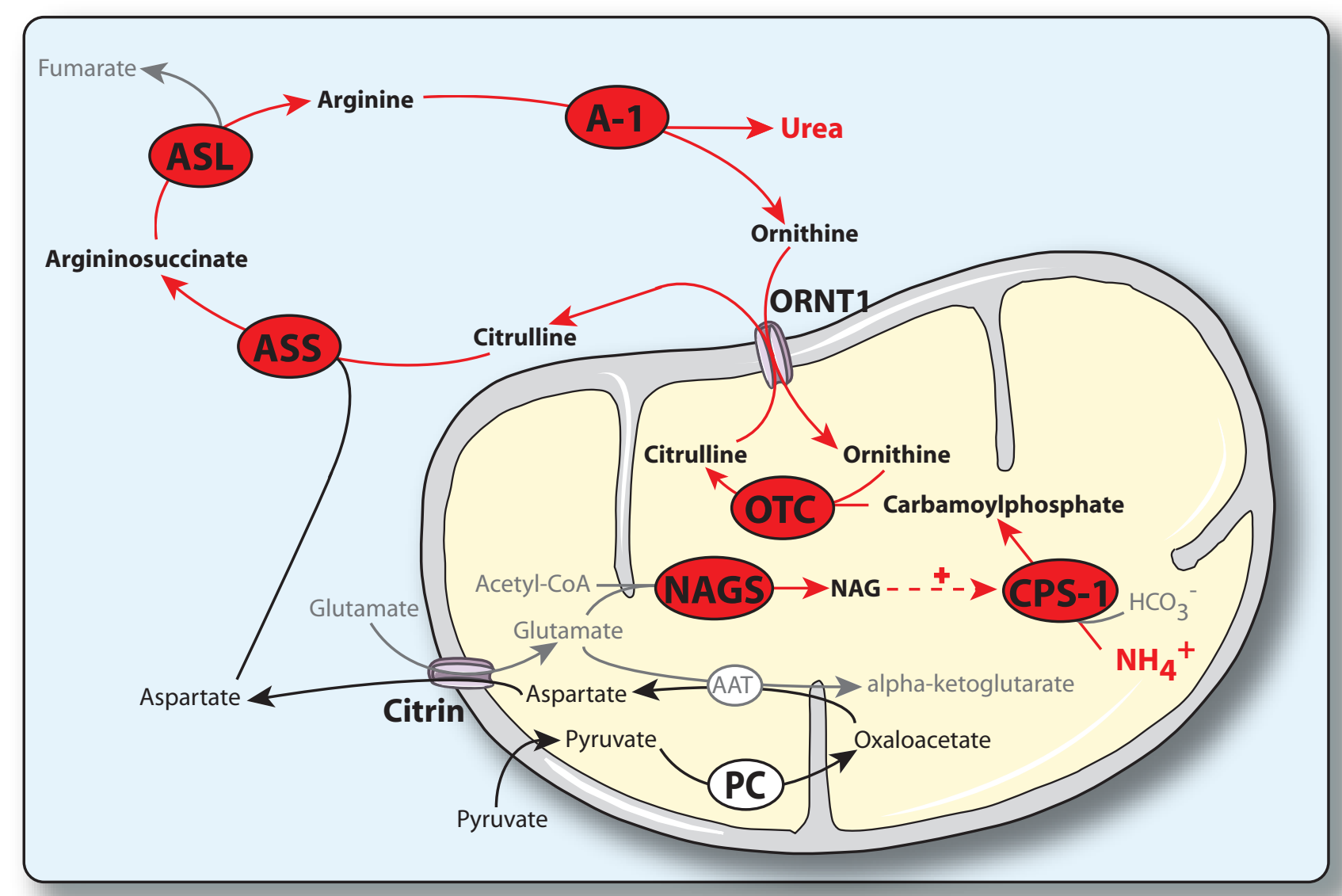




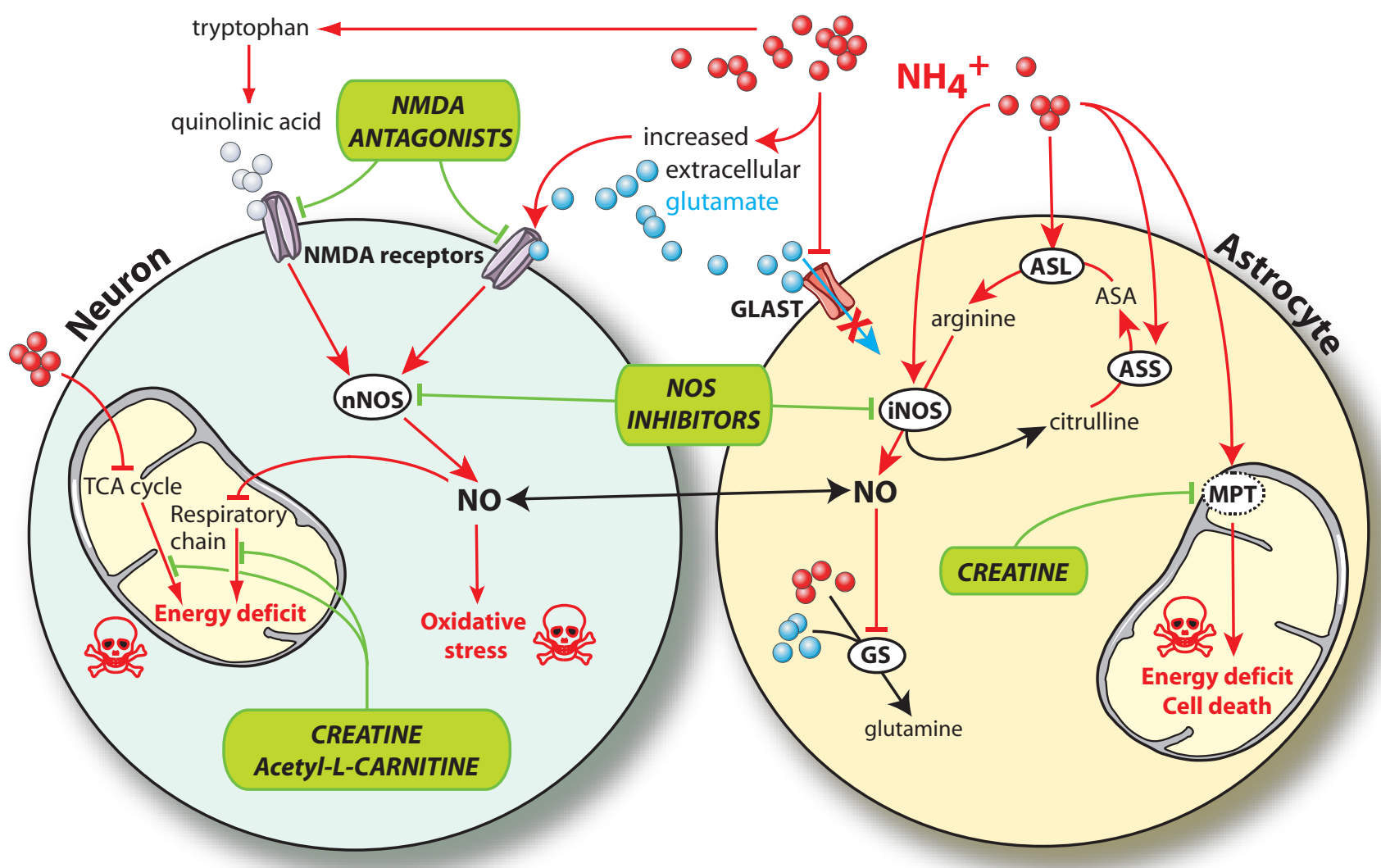




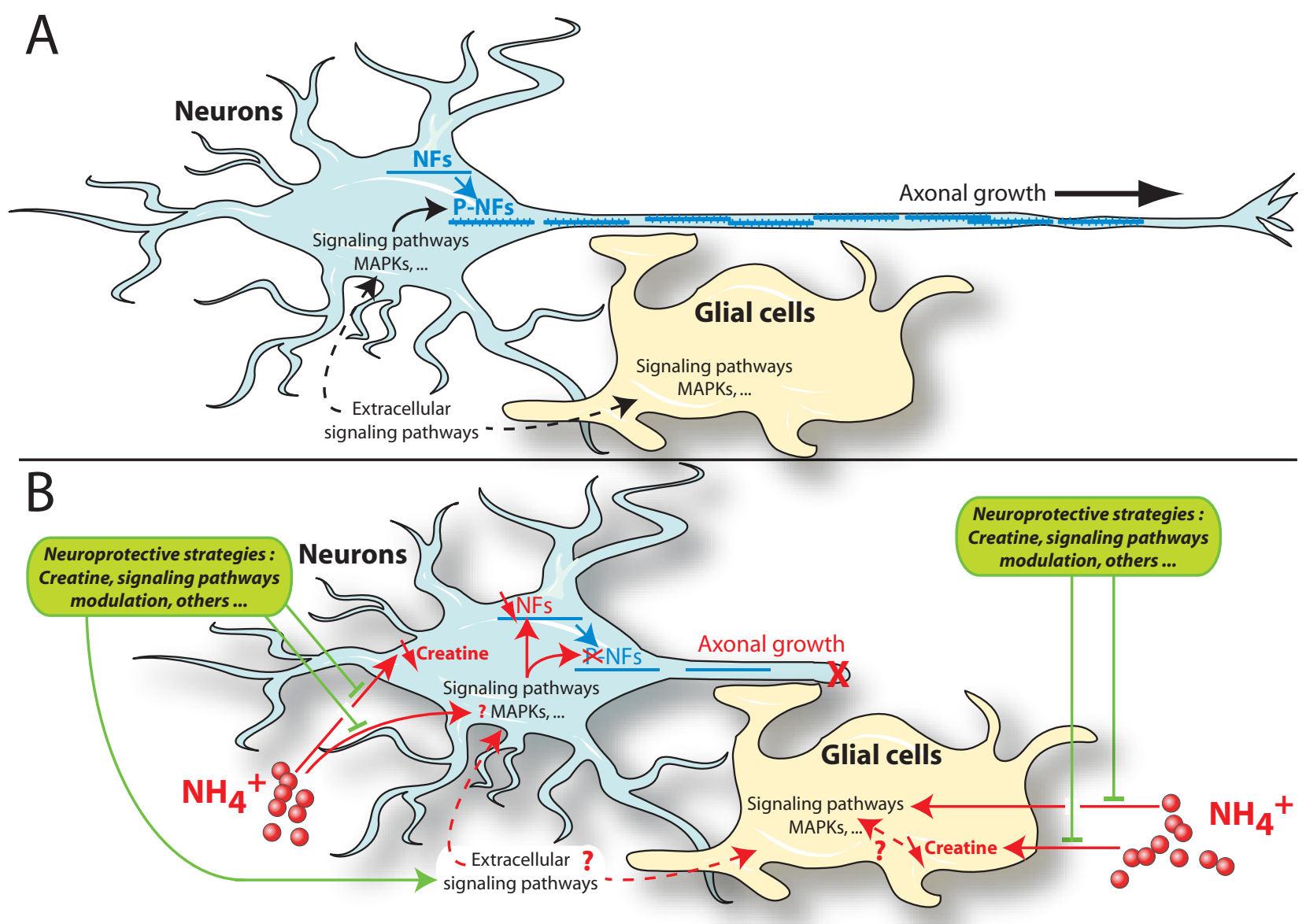

